\title{
A "New" Economic Elite in India: Transnational and Neoliberal?
}

Jivanta Schoettli and Markus PohImann

\section{OpenEdition}

\section{Journals}

\section{Electronic version}

URL: http://journals.openedition.org/samaj/4320

DOI: $10.4000 /$ samaj.4320

ISSN: $1960-6060$

\section{Publisher}

Association pour la recherche sur l'Asie du Sud (ARAS)

\section{Electronic reference}

Jivanta Schoettli and Markus Pohlmann, "A "New" Economic Elite in India: Transnational and Neoliberal? », South Asia Multidisciplinary Academic Journal [Online], 15 | 2017, Online since 06 April 2017, connection on 19 April 2019. URL : http://journals.openedition.org/samaj/4320 ; DOI : 10.4000/ samaj.4320

This text was automatically generated on 19 April 2019

\section{$(1) \Theta \Theta$}

This work is licensed under a Creative Commons Attribution-NonCommercial-NoDerivatives 4.0 International License. 


\title{
A "New" Economic Elite in India: Transnational and Neoliberal?
}

\author{
Jivanta Schoettli and Markus Pohlmann
}

\section{Introduction ${ }^{1}$}

1 India is today one of the world's fastest growing economies, a G-20 major economy, member of the BRICS and a developing economy, which according to the World Trade Organization (WTO) is among the top 20 global traders. ${ }^{2}$ As per the International Monetary Fund's 2015 annual survey, the Indian economy is set to become "one of the fastest-growing, big, emerging market economies in the world" (Cashin et al. 2015). Although the country continues to rank low on indices such as the World Bank's "Ease of Doing Business" and economic reforms have been slow and cumbersome, corporate India has been gaining global recognition and resonance with the rise of internationally successful companies such as Tata, Mahindra, Birla, Reliance. What lies behind these success stories? Is there an Indian model of doing business or is globalization of the company giving rise to a "global business elite"? Is it the case that the managers leading successful global enterprises are internationally recruited, graduates from the best business schools around the world who thus carry, replicate and implant the same ideas and best practices wherever they go? This is the scenario painted by the renowned Harvard Business School scholar, Rosabeth M. Kanter. Her book, World Class: Thriving Locally in the Global Economy applauds "corporate cosmopolitanism," for example in the following way:

Cosmopolitans are card-carrying members of the world class-often literally card carrying, with passports or air tickets serving to admit them. They lead companies that are linked to global chains. Comfortable in many places and able to understand and bridge the differences among them, cosmopolitans possess portable skills and a broad outlook. But it is not travel that defines cosmopolitans-some widely traveled people remain hopelessly parochial-it is mind-set.

Cosmopolitans are rich in three intangible assets, three C's that translate into preeminence and power in a global economy: concepts-the best and latest knowledge and ideas; competence-the ability to operate at the highest standards 
of any place anywhere; and connections-the best relationships, which provide access to the resources of other people and organizations around the world. Indeed, it is because cosmopolitans bring the best and latest concepts, the highest levels of competence, and excellent connections that they gain influence over locals. Cosmopolitans carry these three C's with them to all the places in which they operate. As they do so, they create and become part of a more universal culture...

(Kanter 1995:23-24)

Two specific hypotheses are thus drawn from the globalization literature and tested in this article: (a) the projection that the rise of multinational companies fosters the emergence of a transnational business elite ${ }^{3}$ and, (b) that as economic elites globalize they opt for an education in economics / commerce and graduate from business schools which predisposes them towards neoliberal action orientations.

2 The paper is divided into four sections. A state of the art discusses the two hypotheses mentioned above, their outlook of convergence and place within the broader globalization literature. Next, we introduce the research design, which informed the collection of life course data for more than one hundred top managers. The creation of this original database, admittedly drawn from secondary sources, brings together data on nationality, work and study abroad, educational background, career pattern and mobility. Aside from biographies there is limited data available on Indian top managers. The database thus provides a useful starting point for further in-depth studies using regressions analysis as well as complementing our sample of interviews that were conducted with Indian top managers. Furthermore, the data collection was part of an extensive international research project that collated the same data for other Asian, Latin American and European economies, forming a rich international database. ${ }^{4}$

In this article we analyze and compare the data with a benchmark 1963/64 study conducted by Sagar C. Jain entitled, "Indian Manager: His Social Origin and Career," covering 1,982 Indian managers from manufacturing and processing companies. To contextualize the data, we consider two levels of analysis in part four: (1) the business system and, (2) the organizational form of corporate career systems in India. Our conclusion sums up the main findings and presents comparative data for Asia's main economies.

\section{Theory and State of the Art.}

4 Our research draws upon the classical framework of Max Weber's work on capitalism as a starting point (see Pohlmann 2002, 2005). At an abstract level, Max Weber was interested in how carrier groups with a new spirit of economic thinking became influential in a historical institutional setting, pushing forward the establishment of a new form of capitalism. ${ }^{5}$ This was also the basis for our research questions, whether the recruitment and selection of CEOs fosters the emergence of new forms of neoliberal management thinking. Weber concentrated on three mechanisms of reproduction: the selection of firms and personnel, the diffusion of concepts and ideas, and the adaptation of ideas through socialization processes. In this paper, we concentrate on the selection of the highest ranked personnel in the biggest industrial firms in India to find out how the carrier group ${ }^{6}$ of the capitalist spirit is recruited and what their qualifications are. This combines a focus on elites, ideas and institutions, each intertwined and embedded within an organizational framework. Elites are defined using a positional approach. We do not discuss power elites, who are defined by the exercise of their power, but focus on 
positional elites, defined as those who occupy the highest position in a given sector. They have the potential to exercise power, but we do not know nor do we investigate how influential or powerful they really are. We apply this to the category of managers as well as entrepreneurs. Managers are defined as executive staff (in our sample, usually the Chief Executive Officer, CEO) and entrepreneurs are identified as the owners (stock or majority shareholders) who usually run a company group, as President, General Manager, Chairman or as the CEO.

5 Empirical research suggests that there is tough global competition for prized positions with high incomes and that there is a battle for the best-a global "war for talent"-which is being fought between countries and companies (Dreher 2003:18; Chalamwong 2005:488). Professionals and managers are eminently mobile, pursuing boundary-less careers and, thus contributing to a global economy in which money, goods and people endlessly circulate (Appadurai 1998:15). Three core lines of argument can be drawn from the literature.

6 The emergence of a global elite which can choose to live and work where the costs are low, where it is most beautiful and where the taxes are low (Beck 1997:17) or as Castells has put it, "Elites are cosmopolitan, people are local" (Castells 1996:414). The implicit model behind this claim is close to the neoclassical view of labor markets where rational agents, with no preference for specific exchange partners, circulate within markets without institutional barriers or cultural constraints. Globalization literature suggests that people change their jobs to maximize returns on human capital, as explained by theoretical models based upon a "resources and rewards" logic (Tuma 1976; Hachen 1990). Stiglitz (2002) describes the neoliberal competitive market model as one derived from neo-classical economics where supply always equals demand, including for labor.

7 The emergence of a "transnational capitalist class" (Sklair 2001; Staples 2006; Robinson 2004; Robinson 2011; Carroll 2010) including managers and politicians who are interconnected across countries and companies. Following the flows of commodities and capital, corporate elites become more integrated through interlocking directorates and exchange networks. Subsequently, they are supposed to have more opportunities to switch jobs as well as companies. The explanatory frame here is that of a power-structure network approach to labor markets. Corporate elites use their network opportunities to switch jobs and companies, thus becoming more integrated and international.

8 The growing preference for a "Boundary-less career" (Arthur and Rousseau 1996; Sullivan and Arthur 2006; Thomas and Inken 2007) where the individual follows a career based on personal choice, not one determined or constrained by the organization. Per the neoclassical reward-resource model, which underlies this prediction too, job mobility in labor markets is classified as the voluntary mobility of actors. One that is no longer determined by career paths confined to big organizations. Borderless or boundary-less careers of job- and company-hoppers are assumed to become the new career model for highly-skilled people and CEOs in globalizing economies (Inkson and Elkin 2008). Others have pointed out that the "idea of a boundary-less career has gained little traction outside limited academic-mainly business school-circles, and has limited empirical support. Nonetheless, many academic writers on boundary-less careers have tended not to question the prevalence and importance of the concept but to accept it as common sense." (Roper et al. 2010:673; Rodrigues and Guest 2010:1158). 
Business Schools as the training ground for a global economic elite. It is posited that a management education or the acquisition of a prestigious MBA degree creates the desired managerial habitus, a type of cultural capital. Particularly, within the context of global organization, a shared managerial language and values act as the basis for communication and trust, overcoming forces of fragmentation that have resulted through the globalization of production, work conditions and distribution (Grey and Garsten 2001). Most importantly, "business schools are able to legitimate this (common) language by bestowing the hallmark of intellectualism and perhaps even science." (Grey 2002:502).

The basic idea behind each of these claims is the emergence of worldwide labor markets and networks leads to a global corporate elite of job and company-hoppers; a world class of managers and management, often educated in the best business schools and therefore globally oriented and attuned, like their companies. In this brave new management world, neither institutional nor cultural constraints, nor organizational barriers are of significance anymore. This outlook was captured and promoted by a 1997 McKinsey study, "The War for Talent," in which consultants argued that American firms placed a high premium on degrees from first-tier business schools and especially on newly minted MBAs, as a pre-requisite for success (Michaels et al. 1997). In excellent firms, the report argued, top performers were rewarded inordinately, and promoted without regard for seniority or experience (Michaels et al. 1997). Since then, the talent-mindset, i.e. the "deep-seated belief that having better talent at all levels is how you outperform your competitors," has spread around the world. The following are therefore considered to be necessary and inevitable outcomes of globalization: (1) well-educated people from business schools fill the highest corporate ranks, (2) they move around the globe, switching firms and countries in response to rewards and resources and, (3) they are no longer committed to pursuing a career within one company or state.

However, not everyone agrees that there is a clear trend, or that the incentives are so obvious as to encourage prevalent and widespread global job-hopping. Human capital theory asserts that career mobility has a negative impact on career outcomes because an employee's wages ought to increase over time, in relation to firm tenure. A longer tenure "implies the accumulation of more firm-specific skills, and/or a better match between worker capabilities and job needs" (King et al. 2005:985). Furthermore, there is the argument of segmented labor markets, which rests upon the assumption that promotions usually take place in relation with job tenure, and that external recruitment to fill higher positions is limited (Blossfeld and Mayer 1988:124; Koehler 2014). The internal recruitment of executives is more efficient for both the firm and the executive, where the firm can test employees' skills and abilities and the executive can realize higher rewards if he or she stays with the company. In cross-national and cross-cultural studies on labor markets it has been well-established that institutional constraints have a strong impact on job mobility, including education systems, language barriers, welfare systems and so on (Diprete et al. 1997; Pohlmann 2009). Given that the structure of institutional constraints and inducements differs across nations, it is on the one hand to be expected "that nations will differ in the extent to which institutions shield or channel the impact of structural change on individual outcomes" (Diprete et al. 1997:320). On the other hand, the stays abroad, the return mobility of high skilled professionals and executives back to their mother country or their mother company is expected to be rather high because of these institutional constraints (see for example, Diehl and Dixon 2005; Pohlmann 2009). 

evidence for a "strong" globalization hypothesis or if it fits the expectations of other approaches, mentioned above. While there is much research on the emergence of the "global Indian firm" these have largely focused on internationalization through mergers and acquisitions and the strategies implemented by business groups (see for example the special issue journal on "The Global Indian Firm" edited by Tarun Khanna 2009). The "Indian model" of doing or running a business has made it into the Harvard Business School curriculum, but in the form of case studies. More recently in-depth research has been conducted into how Indian managers are integrating global norms such as Corporate Social Responsibility into their business practices. ${ }^{7}$ This work has drawn attention to how organizational structures translate and transfer global norms, enabling in the process a legitimation of corporate neo-liberalism. Turning to other literature, from the company level to the role of Indian business leaders, the emphasis has been on success stories, rags-to-riches narratives of outstanding individuals or studies of business communities that fostered entrepreneurial skills and dense networks to overcome the historical odds of colonialism or caste in the Indian context (Merchant 1997; Dadabhoy 2005; McDonald 1998).

to comparative case studies where much of the literature has been intertwined with a discussion of capitalism and capitalist development over time (see for example Gilpin 2002). Especially in the business systems literature (Whitley 1999) the argument has long been made, that there is divergence among global models, as well as convergence. Nevertheless, it is the convergence literature that has largely prevailed, harking back to Modernization theories of the 1950s and 60s and further, to a Hegelian idea that history triumphs with the establishment of a final, rational form of society and state. Scholars have mentioned the inadequacy for instance, of the Varieties of Capitalism methodology for non-OECD countries referring in the Indian case to the problem of "compressed capitalism" (D'Costa 2014). This refers to the simultaneous existence of multiple phases of capitalism, depicted in terms of modern industrial capitalist institutions along with agrarian and petty commodity production sectors. The paucity of primary data and limited empirical investigations with regards to India was affirmed recently, in a 2013 article published in the Socio-Economic Review where the authors stated: "India, now the third-largest economy of Asia, is virtually terra incognita from a business systems perspective" (Witt and Redding 2013:267).

, instead of deploying a macro perspective, in this paper we apply a theoretically informed, empirical research design to investigate the reputed effects of globalization at the meso-level of the organization (the firm) and, at the micro-level, the manager's life course. We selected CEOs of the country's leading manufacturing companies (top one hundred that were ranked according to sales turnover). We were unable to collect data on how globalized their activities are. However, there are studies that indicate a wave of internationalization in the Indian manufacturing sector took place from the early $2000 \mathrm{~s}$ (see for example a 2013 study conducted by the Indian School of Business and Brazil's Fundacao Dom Cabralon on the "Transnationality Ranking of Indian Companies"). ${ }^{8}$

Despite the widespread perception that India's economic growth is largely thanks to the tertiary sector and especially, information technology services, manufacturing has been, and is, a highly important component of the country's economic profile. From a rankingaccording to market sales in 2015-of companies listed on the Bombay Stock Exchange,

South Asia Multidisciplinary Academic Journal, 15 | 2017 
seventy-six of the top one hundred and eleven were from the industrial sector. ${ }^{9}$ In the Indian context this includes the following groups of manufactured goods: basic goods (such as aluminum and steel), capital goods (such as machinery), intermediate goods (including auto parts), consumer durables and non-durables (see for example the Annual Report of 2015-16, Government of India, Ministry of Commerce and Industry, Department of Industrial Policy \& Promotion).

With this justification, our empirical exploration limits itself to the industrial manufacturing sector, which dominates the top one hundred ranking of companies as well as contributing substantially to India's merchandise and refined products exports. Using these as our prism we seek to explore whether Indian top managers are becoming more transnational in their careers, and in joining a global elite, whether it can be said they are likely to develop a neo-liberal orientation as a result of MBAs and Business School degrees.

\section{Research Design \& Method of Analysis.}

17 As mentioned above, in the globalization literature there are strong assumptions and expectations of convergence, for example via the impact of globalization on economic elites (Beck 1997; Castells 1996; Münch 2009; Carrol 2010 etc.). Our empirical investigation addresses two hypotheses derived from such discussions:

The "Global Elite" Hypothesis: across the world a global economic elite has emerged, a world class of managers (Sklair 2001; Kanter 1995). Managers are no longer constrained by an organizational career but instead pursue a "protean career," i.e. one that is selfdirected and self-chosen involving various changes of company (Hall 1996; Briscoe et. al. 2006).

The "War for Talent" Hypothesis: as companies internationalize, managers are recruited form the best business schools, and freshly minted MBAs are quickly promoted to the top (Michaels et al. 2001, Faulconbridge et. al. 2009).

We developed a set of indicators and extracted data from an extensive life course analysis of top managers. The life course embeds individual lives in their social structures, and aims at mapping, describing and identifying the synchronic and diachronic features that define a lifetime (Mortimer and Shanahan 2004:3-22). This generated data for statistical analysis, in the form of correlations and regressions, to identify how educational and employment systems, recruitment and careers shape the life course of top managers. We also used our life course data to detect patterns within and across age groups. Thus, the life course is not just the life history of persons as individuals but a manifestation and expression of social structures as well as period and generational effects.

The data presented below pertains to active CEOs in India, related to a ranking of firms in the year 2010 according to sales turnover. ${ }^{10}$ This information was collected using a range of online resources; Curriculum Vitae provided by the respective companies as well as published biographies (for example, Piramal 2010, Piramal 1997). While there may be a bias towards a story of continuity, the life course perspective can alert researchers to the dynamics of change. Thus, for our analysis we separated the sample into three different age groups: CEOs and Ex-CEOs born before 1952, born between 1953 and 1962 and those born after 1963 to gain an impression of the dynamics of change over time. ${ }^{11}$ 
An extremely useful benchmark was an extensive study published in 1971 by Sagar C. Jain entitled, "Indian Manager: His Social Origin and Career." Conducted in 1963-64 with support from Cornell University, The Asia Foundation and the Indian Institute of Management, Calcutta, ${ }^{12}$ the book presents data on 1,982 Indian managers of manufacturing and processing companies including the public sector, foreign enterprises and the Indian private sector. Unlike our 2010 data, the firms in this earlier study were selected based on size (a minimum of 2,000 employees) and the position of manager extended from chief executive to second-level supervisors. Nonetheless, it provides a highly valuable base line with which to compare our findings.

Where possible, data from additional sources were used to supplement, support or challenge our claims about change and continuity since the $1960 \mathrm{~s} .{ }^{13}$ Our findings and conclusions are generally corroborated by the few contemporary empirical studies that exist. The Wharton School study, "The India Way," published in 2010 by Peter Capelli et al. was based on interviews with more than one hundred Indian executives, leading a spectrum of companies. Focusing on leadership skills, company governance, human resources management and innovation, the study found that Indian corporations are less concerned with shareholder interests than Western businesses. Using the life course data, we explore the pre-conditions for a neo-liberal orientation amongst top managers and provide a potential explanation for finding them. Cross-cultural and comparative international studies such as the Globe Study of 62 Societies,${ }^{14}$ INSEAD's Culture and Business Systems of Asia ${ }^{15}$ or IBM's Global CEO study ${ }^{16}$ have generated valuable empirical data and insights into the role of culture, organizations and leadership. While these studies focus on norms, values, beliefs and attitudes they do not explicitly explore the mechanisms and processes of selection and socialization that embed top managers within their socio-cultural context.

\section{A Global Elite in the Upper Echelons of the Indian Economy?}

24 To respond to the broad globalization thesis and our two concrete hypotheses, we examined three indicators: (1) Transnationality: the number of non-Indians who are top managers and the time spent working or studying abroad by Indian top managers; (2) Recruitment \& Mobility Regimes: the typical route and recruitment pattern to reach a top managerial position and whether this corresponds with the notion of a "boundaryless career" (Inkson et al. 2012) and; (3) Educational Background: is there a continued bias towards more traditional degrees such as the Natural Sciences and Engineering or are other subjects like Business \& Administration / Management (in the Indian case, Commerce degrees) growing increasingly prominent?

\subsection{Transnationality amongst Top Managers in India.}

To explore how transnational India's managerial elite is, we first checked how many top managers in the top one hundred list were born and brought up abroad. Second, we ask whether the companies that foreign-born managers worked for were in fact domestic companies or foreign affiliates of multinational companies. Finally, a weaker form of internationality was examined in terms of whether top managers had studied abroad or spent time working abroad. The results from the Indian database are presented below. 
Table 1: Number of CEOs heading top 100 hundred companies in India who were born or had grown up abroad (in 2010)

\begin{tabular}{|l|l|l|l|l|}
\hline $\begin{array}{l}\text { Companies } \\
(\mathrm{N})\end{array}$ & $\begin{array}{l}\text { Foreign } \\
\text { born } \\
\text { CEOs (N) }\end{array}$ & $\begin{array}{l}\text { Foreign born CEOs in } \\
\text { domestic companies } \\
(\mathrm{N})\end{array}$ & $\begin{array}{l}\text { Foreign born CEOs in } \\
\text { Transnational companies } \\
(\mathrm{N})\end{array}$ & $\begin{array}{l}\text { Recruited from } \\
\text { internal labor } \\
\text { markets (N) }\end{array}$ \\
\hline India $\left(100^{*}\right)$ & $5 \%(5)$ & $2 \%(2)$ & $3 \%(3)$ & $3 \%(3)$ \\
\hline
\end{tabular}

*Authors' own data.

Considering other studies, India is not an exception and seems to follow a general pattern of largely domestic nationals dominating the top one hundred list of CEOs (this phenomenon has been observed in the cases of Japan, South Korea and Germany ${ }^{17}$ ). The two foreign-born CEOs in domestic Indian companies are unusual cases in terms of place of birth but both made their careers in India. Mukesh Ambani of Reliance was born in Aden, Yemen as his father was based there at the start of his career and Mr. Yusuf Hamid of Cipla was born in Vilnius, Lithuania because of a mixed-parent marriage. The CEOs who were born and brought up abroad not only worked for a foreign affiliate firm of a multinational company, but were also all expatriates, i.e. sent abroad by the company and not recruited internationally (this is reflected in the fifth column of table 1 which indicates recruitment of managers from the internal labor market of the company itself). It is of interest to note that out of India's one hundred and eleven top manufacturing companies (per sales) there are only six foreign multinationals. Each of these foreign multinationals has a long history of doing business in India and their Indian subsidiaries have a strong local brand and corporate identity. They are listed on the National Stock Exchange of India or the Bombay Stock Exchange with the mother company holding a controlling stake. It therefore does not come as a surprise that out of these six foreign multinationals, four have long had Indian managers at the helm, one recently appointed an Indian national for the first time, and only one has been and continues recruiting its managers from its global operations.

As seen above, it is clearly a home-grown elite that dominates the upper echelons of top management. This feature is confirmed by a study of the Tata group that came to a similar conclusion: "overall, the proportion of foreigners at the apex of Tata companies seems very low and stands in sharp contrast to the fact that in the FY2010-11, 58\% of the Group's total revenues came from international revenues" (Imbach 2012:102). While this indicates a rejection of the global-elites thesis with respect to India, it does not mean that no globalization effect is discernible. The fact that foreign multinationals in India seem to have top managers who were locally recruited, made their way up in the company and spent time abroad, implies they were valued for being locally rooted and global at the same time. However, the more surprising result appears below.

Table 2: Stays abroad to study or work ( $\geq 1$ Year) of Indian Top Managers by Age Groups

\begin{tabular}{|l|l|l|l|l|}
\hline Age Group: & $\begin{array}{l}40-49 \\
50-59\end{array}$ & $60+$ & Total \\
& $(17)$ & $(50)$ & $(44)$ & $(111)$ \\
\hline
\end{tabular}




\begin{tabular}{|l|l|l|l|l|}
\hline $\begin{array}{l}\text { Study Abroad: Yes } \\
(\geq 1 \text { Year })\end{array}$ & $76.5 \%$ & $28 \%$ & $40.9 \%$ & $40.5 \%$ \\
\hline $\begin{array}{l}\text { Work Abroad: Yes } \\
(\geq 1 \text { Year })\end{array}$ & $52.9 \%$ & $24.0 \%$ & $34.1 \%$ & $32.4 \%$ \\
\hline
\end{tabular}

Authors' own data.

28 At first, it is interesting to note the distribution and the bulge amongst older and younger managers indicating that both were and are more likely to spend time abroad. Furthermore, there is a stark preference amongst Indian managers to study but not work abroad, a feature that may be changing amongst younger managers. ${ }^{18}$ Explanations can include the fact that it is only recently that Indian companies have global operations and that in traditional family-firm structures, members may have been sent abroad to study but were expected to return and learn the ropes of business. It is however, important to note that no significant correlation was detected between age and studies or work stays abroad. Older managers in India may have had more international exposure but the middle generation did not have the same opportunities due to the government's socialistic and restrictive policies towards business and a generally closed economy. Older companies are likely to have older managers at the helm, thus reproducing the effect mentioned above.

\subsection{Recruitment \& Mobility in Indian Big Business.}

To explain these findings we turn to our data on recruitment patterns and career mobility. There, we see a strong tendency towards the in-house career system, as presented below. The main explanation for such high figures of insider recruitment and in-house careers is the predominant family company in the Indian context. $45 \%$ of the companies in our sample are family owned, controlled or family-run. As the number of family companies declines, the percentage of insider recruitment drops as in the case of the 50-59 year olds' cohort.

Table 3: Recruitment and Mobility of Top Managers in India

\begin{tabular}{|l|l|l|l|l|}
\hline Age Groups (N) & $\begin{array}{l}40-49 \text { years } \\
(17)\end{array}$ & $\begin{array}{l}50-59 \text { years } \\
(50)\end{array}$ & $\begin{array}{l}60+\text { years } \\
(44)\end{array}$ & $\begin{array}{l}\text { Total } \\
(111)\end{array}$ \\
\hline Insider Recruitment \% & $82.4 \%$ & $73.5 \%$ & $81.8 \%$ & $78.2 \%$ \\
\hline Company Change (Yes) \% & $13.3 \%$ & $37.2 \%$ & $43.6 \%$ & $36.1 \%$ \\
\hline
\end{tabular}

Authors' own data.

Long tenure and in-house careers are strong features of the Indian sample, remaining quite stable over each of the age groups. Again, this is explained by the high number of family-owned companies (50 out of the total sample of 111) and, in the case of state-run companies ( 20 out of the 111 sample), the tendency of senior bureaucrats to be at the helm. The Indian Administrative Service (IAS) is highly prestigious and most senior 
executives of state-owned companies, having taken the very competitive IAS "Civil Services Examination," gradually worked their way up the ranks.

However, the insider career and recruitment pattern is not an unusual phenomenon when compared internationally. Contradicting proponents of the "boundaryless career" (see Banai and Harry 2004 for the additional term "international itinerant") is a 2012 study by the consultancy agency, Booz Allen Hamilton, which revealed that in this year, companies promoted people from within 71 per cent of the time; 26 per cent of incoming CEOs had worked at the same company for their entire career and 81 per cent of new CEOs hailed from the same country in which the company's headquarters were located. ${ }^{19}$ As a result, the "Organization man" (harking back to the original William Whyte book published in 1956) still prevails, contradicting the vision of a protean career promoted by Hall $(1976,1996,2002)$ as one where individuals follow their own values to guide their careers ("values-driven"), taking an independent role in managing their vocation ("selfdirected").

If we turn to independent variables that influence the length taken to reach a CEO position we find that neither an international career, nor study abroad, nor a $\mathrm{PhD}$, nor having attended an elite university matters. Indian corporate families have long demonstrated a tendency to send the family business heir for an MBA abroad (Piramal 1997) and they, in turn, are likely to be fast-tracked to the CEO position. Education qualifications and preferences of top managers in India is therefore the third indicator examined below.

\subsection{Education Background of Indian Top Managers.}

From the education background of Indian top managers we see that this is clearly an elite group, in terms of access to education and career opportunities. Out of the top one hundred and eleven individuals, only 7 did not receive an education beyond formal schooling. These were all in the older age cohort and their biographies indicate reasons such as lack of means or the late 1940s turmoil leading up to India's Independence and Partition of the Subcontinent.

Table 4: Educational Qualifications of Top Managers in India.

\begin{tabular}{|l|l|l|l|l|}
\hline Degree & $\begin{array}{l}40-49 \text { years } \\
(17)\end{array}$ & $\begin{array}{l}50-59 \text { years } \\
(50)\end{array}$ & $\begin{array}{l}60+\text { years } \\
(44)\end{array}$ & $\begin{array}{l}\text { Total } \\
(111)\end{array}$ \\
\hline BA Degree only & $17.6 \%$ & $34.7 \%$ & $46.5 \%$ & $36.7 \%$ \\
\hline MA degree & $76.5 \%$ & $59.2 \%$ & $27.9 \%$ & $49.5 \%$ \\
\hline PhD & $5.9 \%$ & $2 \%$ & $11.6 \%$ & $6.4 \%$ \\
\hline
\end{tabular}

Authors' own data.

The table above shows a clear trend towards managers pursuing a further Master's degree. This is supported by the argument that older managers were likely to begin their careers directly after a BA. If one turns to the subjects studied (table 5 below), there is a predominance of engineering or science degrees amongst the older generation but not a 
complete absence of commerce and management degrees in the same cohort. A small percentage within the older age group also holds MBAs, which is striking and suggests that Indian managers have been oriented towards formal management training over a longer period than might be expected.

Table 5: Subjects \& Combinations of Subjects Studied by Indian Top Managers

\begin{tabular}{|l|l|l|l|l|}
\hline Subject & $\begin{array}{l}40-49 \\
\text { years } \\
(17)\end{array}$ & $\begin{array}{l}50-59 \\
\text { years } \\
(50)\end{array}$ & $\begin{array}{l}60 \\
\text { years } \\
(44)\end{array}$ & $\begin{array}{l}\text { Total } \\
(111)\end{array}$ \\
\hline Only an Engineering or Science degree & $5.9 \%$ & $38 \%$ & $45.5 \%$ & $36 \%$ \\
\hline $\begin{array}{l}\text { Engineering / Science degree followed by a } \\
\text { Management or Commerce Degree }\end{array}$ & $17.6 \%$ & $16 \%$ & $2.3 \%$ & $10.8 \%$ \\
\hline Only Business, Commerce or Economics degree & $35.3 \%$ & $36 \%$ & $13.6 \%$ & $27 \%$ \\
\hline MBA (Yes) & $58.8 \%$ & $26 \%$ & $6.8 \%$ & $23.4 \%$ \\
\hline
\end{tabular}

Authors' own data.

Amongst 50-59 year olds, a majority studied commerce or obtained management degrees, and the MBAs had already increased during this period. Finally, the youngest managers (40-49 years or younger), demonstrate a growing preference for the MBA, giving credence to the possibility that as more top managers obtain business degrees their action orientations are shaped by a transnational curricula and jargon of management. However, when the entire number of active managers for whom data could be collected is considered, only $23.4 \%$ per cent hold an MBA-a rather lower percentage. A 2012 study carried out by INSEAD, the Harvard Business Review and Business Today magazine noted that only 40 per cent of India's top CEOs held an MBA degree, (a higher number due to the inclusion of CEOs from banking and IT in their sample). ${ }^{20}$ In their study of 374 CEOs from 202 publicly traded companies and ranked according to financial performance, only 2 out of the top $10 \mathrm{CEO}$ s held an MBA degree. Furthermore, the study revealed that with an average age of 54 years, many CEOs obtained their MBAs from Indian colleges (the Indian Institutes of Management) during the 1980s, confirming our claim above that this is not a recent development in the Indian case.

\subsection{Top Managers in India over time.}

Breaking down the 2010 data into three age groups reveals the strengthening of a pattern where careers are mostly domestic and in-house; the recruitment of CEOs takes place from within the company's ranks and the top manager's education is increasingly moving towards degrees in commerce and formal management programs. Compared with data from a 1963 to 64 study involving managers who at the time were about 41 years old, this reveals interesting parallels. Adjusting to the structure of the 1963 data, the information is broken down according to type of company (state, private and foreign). ${ }^{21}$ Although the samples of the two datasets are different (in size and composition), we still believe that it gives us insight into trends regarding education and generational trade, during two 
different phases. While the data cannot be compared directly, it still helps us understand the history of business elites in India.

Bar Chart 1: Educational Qualifications of Top Managers in India, 1963 / 64.

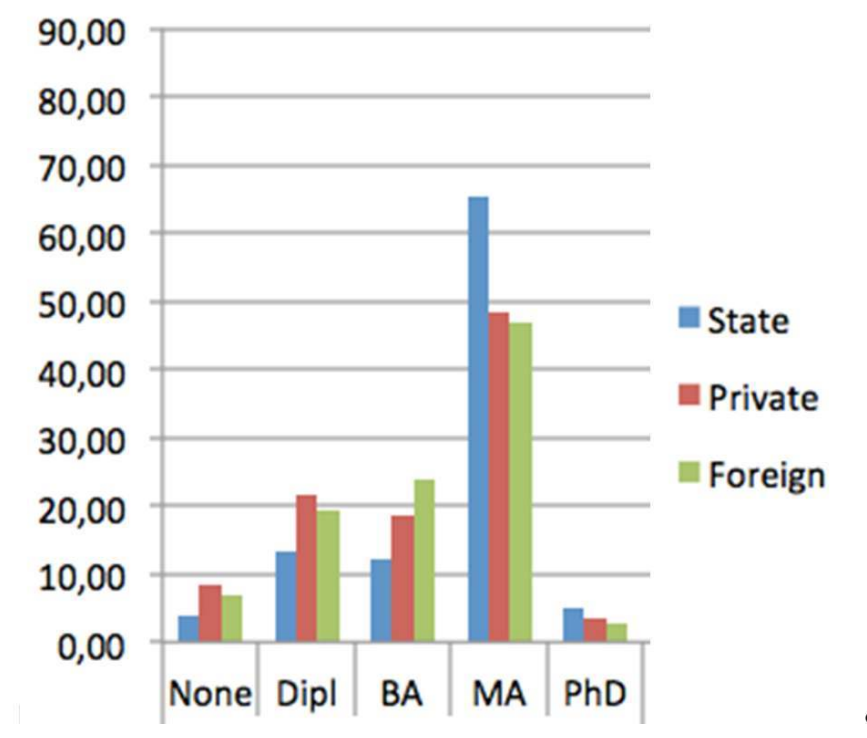

1963 data from Jain (1971): Total Cases 1,982

Bar Chart 2: Educational Qualifications of Top Managers in India 2010.

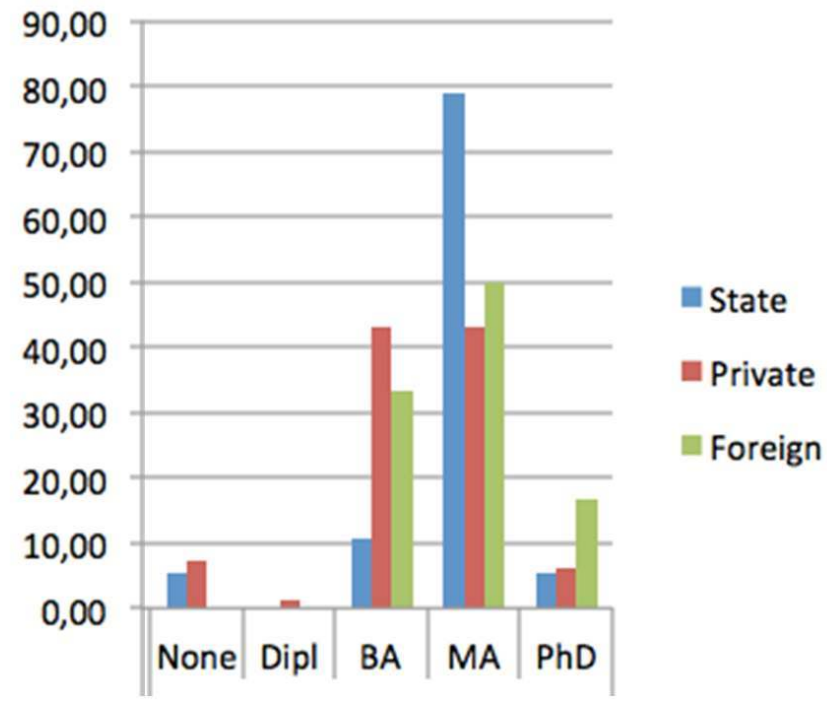

2010 authors' own data. Total Cases 100.

37 In 1963, Jain noted that "a high level formal education (was) one of the basic requirements for entry into managerial positions" (Jain 1971:26) and particularly so in the public sector. This pattern is mirrored in the 2010 data as seen above. Turning to the subjects studied, most managers in 1963 / 64 trained in engineering, technology and natural sciences. 
Bar Chart 3: Major Fields of Study of Managers in India: 1963 / 64.

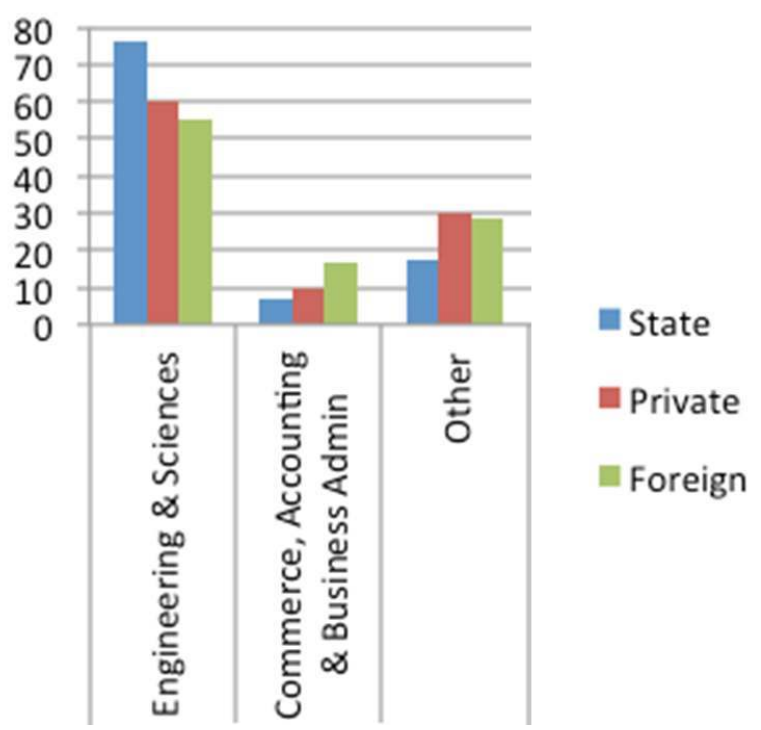

1963 data from Jain (1971): Total Cases: 1,982

Bar Chart 4: Major Fields of Study of Managers in India: 2010.

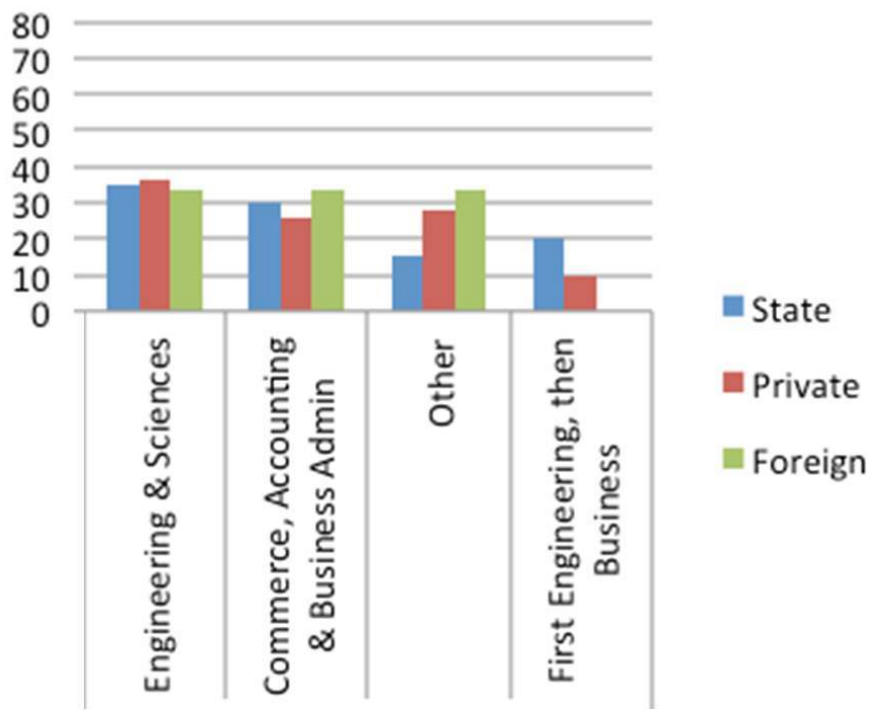

2010 authors' own data: Total Cases: 100

Jain states that, regarding the art and science of management, "Indian managers are largely self-taught persons" but explains this as, partly due to the fact that until 1949 management and business administration were not even recognized as subjects of study in India (Jain 1971:31-33). Clearly this has changed in 2010 when commerce, accounting, management and business administration studies have increased in public, private and foreign companies. However, it is interesting to note that a management-type education in 2010 has not completely displaced engineering and sciences but rather, managers choose to supplement their degrees with an additional management qualification.

With regards to internationality, Jain points out that $17.1 \%$ of Indian managers held foreign degrees, usually at the graduate level and an additional $12.2 \%$ had attended 
training courses of various duration ( 3 months to 2 years) abroad. More than half of these went to England, a quarter to the United States and the remaining to various countries in Europe, Japan and the then-Soviet Union (Jain 1971:36-37). In 2010, Indian managers have clearly become more international with $42.1 \%$ holding foreign degrees and $34 \%$ having worked abroad.

Breaking down his data into four generations Jain observed that, (1) each succeeding generation has more education than the last, (2) the importance of a formal management education and professional training was increasing, including the option of taking shortterm management courses, (3) the average tenure was getting shorter in terms of time taken to reach a top-level position due to the fact that managers were spending more time on education and (4) entry into managerial positions was occurring at a higher level, suggesting a move towards greater external recruitment of top managers (Jain, 1966:1334). Our 2010 data confirms the first two observations by Jain. The Indian top manager is increasingly well educated and there is a marked change in the prevalent subject of study, from engineering and science to economics, accounting and commerce degrees. Over time, a larger and larger percentage opts for MBAs, mostly pursued abroad at elite business schools.

41 However, on Jain's remaining two observations there are marked differences with the 2010 data. At first, average tenure in 2010 remains high, at 29.31 years. Furthermore, while Jain's data indicated an increase in external recruitment, we observe a strong predominance of in-house careers and insider recruitment for top-level managers. Additionally, Jain reports that in 1963 / 64 "only one third of Indian managers have worked for a single employee while many of them have worked for as many as four or more employees" (Jain 1971:166). In 2010, a clear majority, within each age group, worked for a single employee (See Table 3 above). On all three counts of average tenure, being an insider and the number of company changes, managers in India today pursue a stable and conservative career pattern.

\section{Explanations and Contextualization of Findings}

Returning to our initial discussion, whether a transnational elite of business leaders, is emerging as Indian companies go global, this section turns to an explanation of the findings. The typical career path of the contemporary Indian CEO in the manufacturing sector relies strongly upon dynamics of in-house tenure and employer loyalty and secondly, careers remain predominantly national rather than international both in terms of recruitment and mobility patterns. Thirdly, often, Indian top managers are highly qualified in terms of education and demonstrate a growing penchant for business and management programs, especially prestigious programs located abroad. Amongst the younger generation there is an increase in the option of stays abroad, not only for education but also for work.

To explain why the recruitment and career mobility patterns of top managers do not conform to neo-classical expectations of a unified and fluid labor market, we turn to the alternative explanation of segmented labor markets. Segmentation is described in terms of there being internal and external labor markets, the former being a labor market that exists inside the firm. Within large organizations (large in terms of number of employees), there is often an internal market where wage structures and employment policies are regulated and determined internally, conferring significant advantages to 
those already employed in the organization or the "insiders." From the Indian case, two explanations emerge for why an internal market for top managers appears to prevail: (1) the historical and institutional development of India's business system, and (2) organizational features of the company.

\section{1. The Indian Business System.}

In a 2013 article and subsequent book on Asian Business Systems, Michael A. Witt and Gordon Redding examined the "institutional structures" of Asian economies. The main features of India in their study were the role played by the state, especially in terms of influencing capital allocation and the early emergence of a private sector (Witt and Redding 2013:285). Both factors help explain why the CEO career path in India did not develop a more international and transnational pattern but instead veered towards a national, in-house career model. This, even though the 1963 data considered in the earlier section, indicates that Indian big business can draw upon a valuable legacy of managerial professionalism.

According to data from an article published by the economic historian, B.R. Tomlinson a number of British and American multinationals arrived in India during the 1920s and 1930s, setting up manufacturing subsidiaries. ${ }^{22}$ This explains Jain's observation that chief executives in the early 1960s were surprisingly well educated for a developing economy. Jain notes, "In fact, he (the Indian manager) may have more education than his counterparts in the United States and Britain" (Jain 1966:125) since most companies were long established and not newly created by first-time entrepreneurs.

Despite this multinational head start, government policy began to change in the late 1950s with the aim of developing "a socialistic pattern of society," introducing legislation such as the 1956 Industrial Policy Resolution giving more power to the government to direct and plan industrial development and identifying industries where the state would have exclusive responsibility and those where private enterprise could function. Several industries were left open to the private sector but the "license permit raj," as it was called, required permits from the government, ensuring that the state occupied the commanding heights of the economy. Restrictions included controls on capital and imports, culminating with the Monopolies and Restrictive Trade Practices Act of 1969, which ushered in one of the most restrictive periods of the command and control economy in India. Despite increasingly stringent controls introduced in the late 1960s and 70 s, India remained a "mixed economy" with private enterprise continuing to produce goods and services in a highly protected and restricted domestic market.

Continuity of the private sector alongside a dominant state resulted in what Witt and Redding refer to as "multiplexity" where multiple business systems exist within one economy. India and China are two of their prime examples to demonstrate how stateowned and private sectors coexist whilst following different rules of the game. Their line of argument makes the proposition that institutions may be flexible or weak enough to permit variance and the persistence of multiple business systems (Witt and Redding 2014:690). This angle is predominantly top-down, viewing the impact of government policies, regulations and institutions as determining a "business system". However, their analysis does not explore the organizational structures enabling private enterprise to remain resilient in the Indian context, which is what we turn to in the next section. 


\subsection{Organizational resilience in the Indian corporate sector.} sector and family companies and family business groups, have been extremely resilient in the Indian context. ${ }^{23}$ In part thanks to continuity in the legal framework, for instance, activities of Indian companies are regulated through the Companies Act 1956, whose roots go back to the Indian Companies Act of 1913. The 1956 Act aimed to ensure protection of creditors and shareholders as well as allow for greater government control over joint-stock companies in the public interest. Amendments to the 1956 act have targeted issues such as provisions regarding management, corporate government, investor rights and insolvency but concentrated ownership remains dominant. In some cases, family-held companies benefitted from working closely with the government during the time of licenses and restrictions, granting these companies a privileged and protected position in the domestic market. ${ }^{24}$ These companies nevertheless, such as Godrej, Birla and the Tata companies managed to withstand the changes and to compete with new entrants during the 1990s and 2000s including Infosys and Reliance (both, pioneers in terms of entering international capital markets during the 1990s).

While some business houses certainly benefitted, other Indian companies managed to prevail despite restrictions and constraints, both in the past as well as today in what continues to be described as an institutionally weak business environment. ${ }^{25}$ For example, a recent study demonstrates that most Indian firms rely on internal financing rather than external sources such as banks or financial markets (Franklin et al. 2012). The investigation, based on aggregate country-level data, large firm-level samples, and their own surveys of small and medium Indian firms, revealed the tendency to "rely mostly on non-legal deterrents such as loss of business and reputation" (Franklin et al. 2012:442). This points towards the persistence of more traditional methods and business practices that rely on mechanisms such as reputation, personal relationships and trust.

In another study, business journalist Sudipt Dutta who researches family business in contemporary India confirms the above reflections on financial structures and presents additional insights. Family and strong community links continue to aid in networking and capital mobilization for firms. An additional and interesting point is that despite differences in the way one family firm is run compared to another, there is a general tendency to concentrate investments in a smaller portfolio where management control becomes critical. Dutta argues that, "Indian family business retains control through chains of holdings where the wealth of the family remains under control but never gets appropriated to the family or the individual" (Dutta 2011:212). Management control is thus retained even if financial institutions, foreign collaborators or general shareholders have sizeable holdings. Other informal rules include the fact that a percentage holding of equity is not critical given that hostile takeovers within the Indian business community are extremely rare, as networks and reputation are so integral to inter-firm relations in India. The centrality of family-business groups, enduring resilience and density of interlocking networks in the Indian corporate sector has been confirmed in a 2016 publication by Naudet and Dubost on the deepening of interlocks among the top 50, 100 and 250 National Stock Exchange of Bombay companies between 2000 and 2012.

South Asia Multidisciplinary Academic Journal, 15 | 2017 


\section{Conclusion: Globalization and Top Managers in India.}

51 Hall and Soskice noted in their influential 2001 book on the "Varieties of Capitalism" that institutions prevail because of advantages that firms accrue through using national institutional settings and rules. Our paper demonstrates that it is not simply the rational calculus of actors that sustains organizational forms but also the social structures and selection mechanisms that reproduce them. In this paper the focus was on the mechanisms of selection that enabled companies and a managerial class to survive and persist over time-a class not defined by social background but by education and career. In comparison with the 1963 / 64 data our data confirms that education continues to be a very important selection mechanism for top managers and that there is an increasing trend towards management sciences. Career patterns, however, have not continued in the direction indicated by the 1963 / 64 data towards shorter tenure and greater interfirm mobility. Within our database and a 2010 sample across the three age groups, the inhouse career track, based on long tenure with few changes is remarkably stable and does not vary greatly across state, family and privately owned enterprises.

Of course, the 2010 data concentrates on the corporate elite of the manufacturing sector. Perhaps the picture would change if we incorporated the financial or IT sectors. However, this cannot be taken for granted. In a control study on Hong Kong's banking sector, we found that while there is a bigger share of international managers, the number of global job hoppers is also very small. ${ }^{26}$ With an average of three country changes during a top banking manager's career, most of these were carried out within one big bank.

Another reason why we chose to focus on India's manufacturing sector is that it has played an important role in economic growth and international trade, both in the past and increasingly as big-business groups develop a global presence. If the globalization of enterprises leads towards global management then Indian companies should provide an excellent showcase. We operationalized "global management" in terms of career mobility and not global thinking because the latter ought to come naturally for CEOs of the Top 100 companies, running big-business groups with affiliated firms around the world. Most of these CEOs are frequent international travelers, spending a considerable number of their working hours abroad. If we relate our findings on India to other Asian economies, we find similar patterns in job mobility.

Table 6: Job Mobility in Asian Economies

\begin{tabular}{|l|l|l|l|}
\hline Country (N) & Foreign-born CEOs (N) & Job Tenure/years & Insider Recruitment \% \\
\hline China (155) & $4 \%(4)$ & 24 & $97 \%$ \\
\hline Japan (104) & $4 \%(5)$ & 38 & $99 \%$ \\
\hline Korea (121) & $9 \%(14)$ & 31 & $100 \%$ \\
\hline India (100) & $5 \%(5)$ & 30 & $78 \%$ \\
\hline
\end{tabular}

AUTHORS' OWN DATA BASED ON TOP 100 MANUFACTURINg COMPANIES IN EACH OF THE COUNTRIES. 

CEOs who have grown up abroad seem to be typical features amongst CEOS in Asia's leading economies. India is no exception here, although the insider recruitment rates are slightly lower. Along these lines, India fits a more general Asian pattern, despite its other peculiarities and significant differences with other major economies in Asia.

In India, due to its democratic political system, even under a socialist and closed economy, the institutional environment evolved slowly and gradually and has not been a motor for drastic organizational change. All three organizational forms, state-owned companies, private and family-owned businesses have co-existed and continued during various phases of India's economic development, adjusting to both state and marketdriven incentives. Organizational features such as the long, in-house career path of the Indian top manager combined with high education qualifications have therefore been preserved. These features also make sense in an environment where networks, stakeholdership, trust, loyalty and reputation continue to play an important role given the country's business conditions.

However, the preference to study and work abroad appears to be on the rise, as is the demand for management degrees. This could indicate that the grounds for a future wave of transnational careers and neo-liberal managerial orientations are being laid. However, the Indian case also represents the revival of a past trend that was interrupted during the 1970s and 80s. This implied continuity, despite change, is important to highlight for it reveals how strong organizational structures are in the face of macro developments. Currently, the labor market for Indian top managers remains very much Indian, with long job tenure and insider recruitment favored over job-hopping and global head-hunting at the level of the CEO.

\section{BIBLIOGRAPHY}

Appadurai, Arjun. 1998. "Globale ethnische Räume. Bemerkungen und Fragen zur Entwickelung einer transnationalen Anthropologie.” Pp. 11-40 in Perspektiven der Weltgesellschaft, edited by U. Beck. Frankfurt-Main: Suhrkamp.

Arthur, Michael B. and Denise M. Rousseau, eds. 1996. The Boundaryless Career: A New Employment Principle for a New Organizational Era. New York: Oxford University Press.

Banai, Moshe and Wes Harry. 2004. "Boundaryless Global Careers. The International Itinerant." International Studies of Management and Organization 34(3): 96-120.

Beck, Ullrich. 1997. Was ist Globalisierung? Irrtümer des Globalismus - Antworten auf Globalisierung. Frankfurt-Main: Suhrkamp.

Blossfeld, Hans Peter and Karl Ulrich Mayer. 1988. "Labor Market Segmentation in the Federal Republic of Germany: An Empirical Study of Segmentation Theories from a Life Course Perspective." European Sociological Review 4(2) September: 123-40. 
Briscoe, Jon P., Douglas T. Hall and Rachel L. Frautschy DeMuth. 2006. "Protean and Boundaryless Careers: An Empirical Exploration.” Journal of Vocational Behavior 69: 30-47.

Capelli, Peter, Harbir Singh, Jitendra Singh and Michael Useem. 2010. The India Way: How India's Top Business Leaders Are Revolutionizing Management. Boston, MA: Harvard Business Press.

Carroll, William. 2010. The Making of a Transnational Capitalist Class: Corporate Power in the 21st Century. London: Zed.

Cashin, Paul et al., eds. 2015. "India. Selected Issues." International Monetary Fund, IMF Country Report No. 15/62.

Castells, Manuel. 1996. The Rise of the Network Society: The Information Age: Economy, Society, and Culture. Oxford, Malden: Blackwell.

Chalamwong, Yongyuth. 2005. "The Migration of Highly Skilled Asian Workers to OECD Member Countries and its Effects on Economic Development in East Asia." Policy Coherence Towards East Asia, Development Challenges for OECD Countries. Development Center Studies. Paris: OECD.

Chandavarkar, Rajnarayan. 2003. The Origins of Industrial Capitalism in India: Business Strategies and the Working Classes in Bombay. Cambridge: Cambridge University Press.

Chibber, Vivek. 2003. Locked in Place: State-Building and Late Industrialization in India. Princeton: Princeton University Press.

D'Costa, Anthony P. 2014. "Compressed Capitalism and Development. Primitive Accumulation, Petty Commodity Production, and Capitalist Maturity in India and China." Critical Asian Studies 46 (2): $317-44$.

Dadabhoy, B. 2005. Jeh, A Life of J.R.D. Tata. New Delhi: Rupa and Co.

Das, Gurcharan. 2002. India Unbound: The Social and Economic Revolution from Independence to the Global Information Age. New York: Anchor Books.

Diehl, Claudia and David Dixon. 2005. "Zieht es die Besten fort? Ausmaß und Formen der Abwanderung deutscher Hochqualifizierter in die USA.” Kölner Zeitschrift für Soziologie und Sozialpsychologie 57: 714-34.

Diprete, Thomas A., Paul M. de Graaf, Ruud Luijkx, Michael Tahlin and Hans-Peter Blossfeld. 1997. "Collectivist versus Individualist Mobility Regimes? Structural Change and Job Mobility in Four Countries." American Journal of Sociology 103(2): 318-58

Dreher, Sabine. 2003. "Vom Wohlfahrtsstaat zum Wettbewerbsstaat? Die Bedeutung der Migration für die Globalisierungsdebatte." Pp. 13-31 in Migration im Wettbewerbsstaat, edited by U. Hunger and B. Santel. Opladen: Leske + Budrich.

Dutta, Sudipt. 2011. “Family Firms in Present-Day India.” Pp. 209-23 in. The Oxford India Anthology of Business History, edited by M. Kudaisya. Oxford: Oxford University Press.

Faulconbridge, James R., Jonathan V. Beaverstock, Sarah Hall and Andrew Hewiston. 2009. "The 'War for Talent,' The Gatekeeper Role of Executive Search Firms in Elite Labour Markets." Geoforum 40: 800-08.

Franklin, Allen, Rajesh Chakrabarti, Sankar De, Jun Qian and Meijun Qian. 2012. "Financing Firms in India." Journal of Financial Intermediation 21(3): 409-45.

Gilpin, Robert. 2002. The Challenge of Global Capitalism: The World Economy in the $21^{\text {st }}$ Century. Princeton: Princeton University Press.

Grey, C. 2002. "What are Business Schools for?" Journal of Management Education 25(5): 496-511. 
Grey, Chris and Christina Garsten. 2001. "Trust, Control and Post-Bureaucracy." Organization Studies March 22: 229-50.

Hachen, David S. 1990. “Three Models of Job Mobility in Labor Markets.” Work and Occupations 17: $320-54$.

Hall, Douglas T. 1976. Careers in Organizations. Glenview, IL: Scott, Foresman.

Hall, Douglas T. 1996. "Protean Careers of the $21^{\text {st }}$ Century." Academy of Management Executive 10: 8-16.

Hall, Douglas T. 2002. Protean Careers In and Out of Organizations. Thousand Oaks, CA: Sage.

Hall, Peter A. and David Soskice. 2001. Varieties of Capitalism: The Institutional Foundations of Comparative Advantage. Oxford: Oxford University Press.

Hambrick, Donald C. and Phyllis A. Mason. 1984. "Upper Echelons: The Organization as a Reflection of Its Top Managers." The Academy of Management Review 9(2): 193-206.

Hartmann, Michael and Johannes Kopp. 2001. “"Elitenselektion durch Bildung oder durch Herkunft?' Promotion, soziale Herkunft und der Zugang zu Führungspositionen in der deutschen Wirtschaft." Kölner Zeitschrift für Soziologie und Sozialpsychologie 53: 436-66.

House, Robert J., Paul J. Hanges, Mansour Javidan, Peter W. Dorfman and Vipin Gupta, eds. 2004. Culture, Leadership, and Organizations: The GLOBE Study of 62 Societies. Thousand Oaks, CA: Sage.

IBM. 2011. Capitalising On Complexity: Insights from the Global CEO Study.

Imbach, Mathias 2012. “India's Conglomerate Captains: Top Management Team Composition and Internationalization at the Tata Group." PhD dissertation, Betriebswirtschaftslehre, Universität St. Gallen.

Inkson, Kerr, Hugh Gunz, Shiv Ganesh and Juliet Roper. 2012. "Boundaryless Careers: Bringing Back Boundaries." Organization Studies 2012: 323-40.

Inkson, Kerr and Graham Elkin. 2008. "Landscape with Travelers: The Context of Careers in Developed Nations." Pp. 69-94 in International Handbook of Career Guidance, edited by R. van Esbroeck and J. Athanasou. New York: Springer.

Jain, Sagar C. 1966. "The Man in the Gray Flannel Achkan." Columbia Journal of World Business Fall 1 (4): 123-36.

Jain, Sagar C. 1971. Indian Manager: His Social Origin and Career. Bombay: Somaiya Publications.

Kalberg, Stephen. 2001. The Protestant Ethic and the Spirit of Capitalism: New Translation and Introduction. Los Angeles, CA: Roxbury Publishing.

Kanter, Rosabeth Moss. 1995. World Class: Thriving Locally in the Global Economy. New York: Simon and Schuster Inc.

Khanna, Tarun, ed. 2009. “The Global Indian Firm.” A Special issue of The Indian Journal of Industrial Relations 45(1): 1-59.

King, Zella, Simon Burke and Jim Pemberton. 2005. "The 'Bounded' Career: An Empirical Study of Human Capital, Career Mobility and Employment Outcomes in a Mediated Labor Market." Human Relations 58(8): 981-1007.

Koehler, Christoph, Sebastian Barteczko, Stefan Schröder, Karl-Friedrich Bohler. 2014. “Der Arbeitskraftunternehmer ist tot-es lebe der Arbeitskraftunternehmer! Anmerkungen zur Frage der Selbstvermarktung abhängig Beschäftigter." Arbeits- und Industriesoziologische Studien 7(1): 109-25.

South Asia Multidisciplinary Academic Journal, 15 | 2017 
Krichewsky, Damien. 2014. "The Socially Responsible Company as a Strategic Second-Order Observer: An Indian Case." MPIfG Discussion Paper 14/10, Max Planck Institute for the Study of Societies, Cologne: 1-2.

Lanvin, Bruno and Paul E. Evans. 2013. The Global Talent Competitiveness Index 2013, INSEAD.

McDonald, Haimish. 1998. The Polyester Prince: The Rise of Dhirubhai Ambani. St. Leonards, N.S.W.: Allen \& Unwin.

Merchant, Minhaz. 1997. Aditya Vikram Birla: A Biography. New Delhi: Viking.

Michaels, Ed, Beth Axelrod and Helen Handfield-Jones. 2001. The War for Talent. Boston, MA: Harvard Business School Press.

Mortimer, Jeylan T. and Michael J. Shanahan, eds. 2004. Handbook of the Life Course, Heidelberg: Springer.

Münch, Richard. 2009. Globale Eliten, lokale Autoritäten: Bildung und Wissenschaft unter dem Regime von PISA. Frankfurt-Main: Suhrkamp.

Naudet, Jules and Claire-Lise Dubost. 2016. "The Indian Exception: The Densification of the Network of Corporate Interlocks and the Specificities of the Indian Business System (2000-2012)." Socio-Economic Review: 1-30.

Piramal, Gita. 1997. Business Maharajas. New Delhi: Penguin.

Piramal, Gita. 2010. Business Legends. New Delhi: Penguin.

Pohlmann, Markus and Hyun-Chin Lim. 2014. “A New 'Spirit' of Capitalism? Globalization and its Impact on the Diffusion of Neoliberal Management Thinking in Germany and the East Asian Economies." Development and Society 43(1): 1-32.

Pohlmann, Markus and Hyun-Chin Lim. 2009. "Globale ökonomische Eliten? Eine Globalisierungsthese auf dem Prüfstand der Empirie.” Kölner Zeitschrift für Soziologie und Sozialpsychologie 61(4): 513-534.

Pohlmann, Markus and Hyun-Chin Lim. 2005. "Die neue Kulturtheorie und der Streit um Werte." Soziologische Revue 28(1): 3-14.

Pohlmann, Markus and Hyun-Chin Lim. 2002. "Management, Organisation und Sozialstruktur: zu neuen Fragestellungen und Konturen der Managementsoziologie." Pp. 227-44 in Managementsoziologie: Perspektiven, Theorien, Forschungsdesiderate, edited by R. Schmidt, H. Gergs and M. Pohlmann. Mering: Rainer Hampp Verlag.

Robinson, William I. 2004. A Theory of Global Capitalism: Production, Class and State in a Transnational World. Baltimore: Johns Hopkins University Press.

Robinson, William I. 2011. "Global Capitalism Theory and the Emergence of Transnational Elites," Critical Sociology 38(3): 349-63.

Roper, Juliet, Shiv Ganesh and Kerr Inkson. 2010. "Neoliberalism and Knowledge Interests in Boundaryless Careers.” Discourse, Work, Employment and Society 24(4): 661-79.

Rothermund, Dietmar. 1993. An Economic History of India: From Pre-colonials Times to 1991. London: Routledge.

Rodrigues, Ricardo A. and David Guest. 2010. "Have Careers Become Boundaryless?" Human Relations 63(8): 1157-75.

Rudolph, Susanne and Lloyd Rudolph. 1987. In Pursuit of Lakshmi: The Political Economy of the Indian State. Chicago: Chicago University Press. 
Sklair, Leslie. 2001. The Transnational Capitalist Class. London: Blackwell.

Staples, Clifford L. 2006. "Board Interlocks and the Study of the Transnational Capitalist Class." Journal of World-Systems Research December XII(2): 309-319.

Stiglitz, Joseph E. 2002. Globalization and Its Discontents. New York, London: W.W. Norton \& Company.

Sullivan, Sherry E. and Michael B. Arthur. 2006. "The Evolution of the Boundaryless Career Concept: Examining Physical and Psychological Mobility." Journal of Vocational Behavior 69(1): 1929.

Thomas, David C. and Kerr Inkson. 2007. "Careers Across Cultures." Pp. 451-70 in Handbook of Career Studies, edited by H. Gunz and M. Peiperl. Los Angeles: Sage.

Tomlinson, B.R. 1978. “Foreign Private Investment in India 1920-1950." Modern Asian Studies 12(4): $655-77$.

Tuma, Nancy Brandon. 1976. "Rewards, Resources and the Rate of Mobility." American Sociological Review 41: 338-60.

Weber, Max. 1968. Economy and Society: An Outline of Interpretive Sociology. New York: Bedminster Press.

Witt, Michael A. and Gordon Redding. 2013. "Asian Business Systems: Institutional Comparison, Clusters and Implications for Varieties of Capitalism and Business Systems Theory." SocioEconomic Review 11(2): 265-300.

Witt, Michael A. and S.G. Redding, eds. 2014. The Oxford Handbook of Asian Business Systems. Oxford: Oxford University Press.

\section{NOTES}

1. We are grateful to the anonymous reviewers for their substantive comments and critique.

2. See the WTO's International Trade Statistics 2014.

3. We use the term elite with reference to discussions about the emergence of a new world class of business elites (see Hartmann and Kopp 2001).

4. See International Management Studies, Heidelberg University, which brings together a number of related research projects: https://www.soz.uni-heidelberg.de/?page_id=1086

5. See Weber (1968:468-518), Kalberg (2001).

6. The focus on carrier groups is similar to the argument made by Hambrick and Mason (1984) in their seminal paper, "Upper Echelons: The Organization as a Reflection of Its Top Managers."

7. See for example Krichewsky's work on CSR in India (2014).

8. For a summary of the study see, http://isbinsight.isb.edu/ranking-indias-transnationalcompanies/. Retrieved December 29, 2016.

9. http://www.moneycontrol.com/stocks/marketinfo/netsales/bse/index.html. Retrieved March 25, 2015.

10. The ranking used was the ET500 list of companies according to sales turnover: http:// economictimes.indiatimes.com/marketstats/pid-53,pageno-1,sortby-

CurrentYearRank,sortorder-asc,year-2010.cms

11. We realise that creating age groups out of the single 2010 sample is an artificial way of capturing change but due to paucity of data, a time series analysis was not possible.

12. A 1966 article summarises the main findings in: Jain, Sagar C. 1966. "The Man in the Gray Flannel Achkan" Columbia Journal of World Business 1(4): 123-36. 
13. For example, the unpublished but electronically available $1987 \mathrm{PhD}$ thesis by Vyakarnam, Shailendra, "The Social Relevance of Postgraduate Management Education. A Case Study of India," Cranfield University. Accessible at: https://dspace.lib.cranfield.ac.uk/handle/1826/4172

14. R. J. House, P. J. Hanges, M. Javidan, P. W. Dorfman \& V. Gupta, eds. "Culture, Leadership, and Organizations: The GLOBE study of 62 societies." Thousand Oaks, CA: Sage.

15. Bruno Lanvin, Paul A. L. Evans. 2013. "The Global Talent Competitiveness Index 2013." INSEAD, November; Michael A. Witt, Gordon Redding, eds. 2014. The Oxford Handbook of Asian Business Systems. Oxford University Press.

16. IBM (2011): “Capitalising On Complexity. Insights from the Global CEO Study." IBM

17. Pohlmann (2014)

18. A trend that was also detected in the 2012 study on the Tata Group (Imbach: 105)

19. For the details of the 2012 report see: http://www.strategyand.pwc.com/global/home/whatwe-think/reports-white-papers/article-display/time-for-new-ceos. Retrieved March 10, 2015.

20. For a brief overview of the study, see: https://hbr.org/2012/01/the-best-indian-ceo-listyouth. Retrieved March 24, 2015.

21. In the 1963 study, unlike our 2010 study, the definition of managers was broader. According to Jain, the sample included "all persons occupying positions higher than second level supervisors up to and including the managing directors or the chief executives of the concerns" (1971:18).

22. B. R. Tomlinson. 1978. “Foreign Private Investment in India 1920-1950." Modern Asian Studies 12(4): 655-77.

23. According to The Oxford India Anthology of Business History, "in twenty-first century India, as many as 461 out of 500 of the most valuable companies remain under family control" (2011:202).

24. This has been documented by many including, Gita Piramal (1997), Gurcharan Das (2002), Vivek Chibber (2003).

25. See the March 2015 IMF country report No. 15 / 62 available at: https://www.imf.org/ external/pubs/ft/scr/2015/cr1562.pdf. Retrieved April 21, 2015.

26. Bitsch, K. 2016. "Auf den Spuren der globalen Finanzelite-Karriereverläufe und Werthaltungen von Top-Managern im Finanzsektor Hongkongs" (unpublished thesis).

\section{ABSTRACTS}

Much of the globalization literature and accompanying theory project that, as countries integrate into the global economy, they will converge towards a transnational and neoliberal version of capitalism. It is presumed that this happens with the rise of international companies, which along with a transnational class of managers, enable the spread of neoliberal management thinking. In the wake of liberalization policies and reforms as well as the globalization and growth of India's economy, and using life course data for more than one hundred Indian top managers, including information on nationality, time spent working and studying abroad, education background, career and mobility patterns, we explore the evidence for the emergence of a transnational and neo-liberal business elite in India. In the Indian case, we find that top managers are not composed of "transnational rootless company hoppers" but are dominated by "nationally recruited company men." 
INDEX

Keywords: India, economic elites, transnational, globalization, manufacturing companies, lifecourse analysis, top managers

\section{AUTHORS}

JIVANTA SCHOETTLI

Visiting Research Fellow, Institute of South Asian Studies, National University of Singapore

\section{MARKUS POHLMANN}

Prof., Dr., Heidelberg University (Germany), Max-Weber-Institute of Sociology 